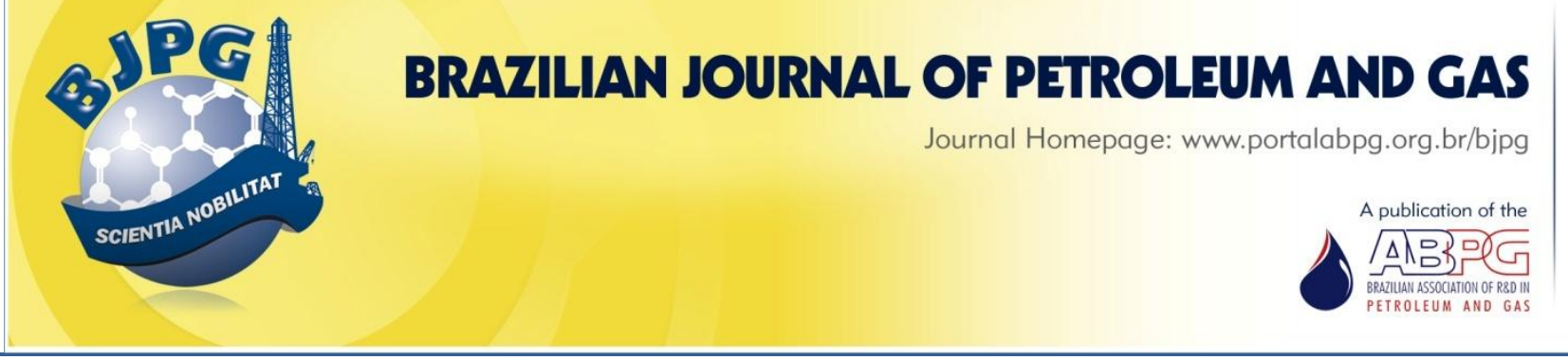

\title{
REMOVAL OF ORGANIC CONTAMINANTS FROM A SYNTHETIC OILFIELD PRODUCED WATER BY ADSORPTION PROCESS USING VEGETABLE AND BONE BOVINE ACTIVATED CARBONS
}

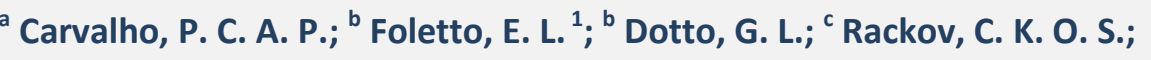

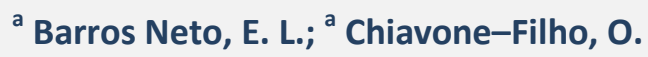

${ }^{\text {a }}$ Federal University of Rio Grande do Norte, Department of Chemical Engineering, Natal - RN - Brazil

${ }^{b}$ Federal University of Santa Maria, Department of Chemical Engineering, Santa Maria - RS - Brazil

c University of São Paulo, Department of Chemical Engineering, São Paulo - SP - Brazil

Received: 11.06.2019 / Revised: 19.08.2019 / Accepted: 26.08.2019 / Published on line: 08.10.2019

\begin{abstract}
The production of oil and gas is usually accompanied by the production of waste water, which contains several organic pollutants. The objective of this work is to investigate the removal of organic load from synthetic oilfield produced water by adsorption process, using activated carbons from vegetable and animal origin. The synthetic oilfield produced water was constituted by a mixture of xylene, n-heptane, phenol, and $\mathrm{NaCl}$ in aqueous solution. The structural properties of the samples were investigated by X-ray powder diffraction (XRD), Fourier transform infrared spectroscopy (FTIR), $N_{2}$ adsorption-desorption isotherms, and scanning electron microscopy (SEM). Effects of temperature and type of adsorbent on the adsorption process were investigated. According to the results, the temperature of $25{ }^{\circ} \mathrm{C}$ was more favorable in adsorption of organic load from synthetic oilfield produced water. Pseudo-first order, pseudo-second order, and Elovich equations were able to represent the adsorption kinetics. The vegetable activated carbon delivered the best results, being the most efficient to remove the organic load due its high surface area. The adsorption capacities were 28 and $15 \mathrm{mg}_{\text {Tос }} \mathrm{g}^{-1}$, for vegetable and animal activated carbons, respectively.
\end{abstract}

\section{KEYWORDS}

synthetic produced water; adsorption; vegetable carbon; bovine bone

\footnotetext{
${ }^{1}$ To whom all correspondence should be addressed.

Address: : Federal University of Santa Maria, Department of Chemical Engineering, Santa Maria - RS, Brazil. ZIP Code: 97105-900 | e-mail: efoletto@gmail.com doi:10.5419/bjpg2019-0017
} 


\section{INTRODUCTION}

Oilfield produced water (OPW) is an aqueous fraction generated in oilfields simultaneously to the production of oil and gas. Among the aspects of OPW that deserve attention, are the high volume and complexity of the chemical composition (Amini et al., 2012). This aqueous fraction generally contains organic compounds such as benzene, toluene, ethylbenzene, xylene, phenols, naphthalene, phenanthrene, dibenzothiophene, polycyclic aromatic hydrocarbons, dispersed oil, metal traces, dissolved inorganic salts, chemical additives, and suspended solids (Faksness et al., 2004; Dórea et al., 2007). Therefore, the presence of the chemical components characterizes the OPW as detrimental to the environment. Its improper disposal can cause harmful effects to the environment, which implies a high cost for a corrective action.

OPW has been treated using of a variety of technologies, such as membrane filtration (Szép \& Kohlheb, 2010), coagulation/flocculation (Santana et al., 2010; Xu et al., 2015), flotation (Silva et al., 2015a), advanced oxidation processes (Gao et al., 2004; Silva et al., 2015b), adsorption (Scurtu et al., 2009), electrochemical method (Jain et al., 2015), biological treatment (Shpiner et al., 2007) and solvent extraction (Oliveira et al., 2014). Adsorption has advantages over the other methods because it has a simple design, it demands low investment in terms of initial cost, allowing the separation of various components with low energy consumption (Rashed, 2013; Dotto et al., 2016).

Due to the large surface area, porosity, and high adsorption capacity (Georgin et al., 2016), activated carbons are regarded as suitable adsorbents for the removal of organic pollutants from liquid effluents. Activated carbons have been used as an effective adsorbent for the removal of organic compounds such as benzene (Mazlan et al., 2016), toluene (Izquierdo et al., 2013), and phenol (Zhang et al., 2016). It should be highlighted that the majority of the studies presented in the literature uses activated carbon from different origins to remove organic compounds from synthetic single (one organic compound dissolved in water) systems. Based on the best of our knowledge, the comparison of adsorption capacity between vegetable and animal bone activated carbons for the removal of organic pollutants contained in the OPW is yet to be investigated.

In this context, this work aims to evaluate the removal of total organic carbon (TOC) from synthetic OPW using activated carbons of vegetable and animal origins. The adsorbents were characterized in detail. Effects of activated carbon types and temperature on the TOC adsorption capacity were investigated. Adsorption kinetic equations were used to interpret the results.

\section{MATERIALS AND METHODS}

\subsection{Adsorbents and characterization techniques}

Adsorption experiments were performed using two commercial activated carbons: vegetable activated carbon (VAC) (sample produced from babassu coconut husk provided by Peixe Bello Company, Brazil) and bone activated carbon (BAC) (sample produced from bovine bone by the BONECHAR Company, Brazil). Average particle size for both samples was $12 \mathrm{~mm}$. Properties of activated carbon samples were analyzed by X-ray diffraction (XRD) (Rigaku Miniflex 300 diffractometer), Fourier transform infrared spectroscopy (FTIR) (Perkin Elmer instrument), $\mathrm{N}_{2}$ adsorption-desorption isotherms (Quantachrome instruments) and scanning electron microscopy (SEM) (JEOL, JSM-6060).

\subsection{Adsorption assays}

Synthetic OPW was prepared from the dissolution of xylene $\left(10 \mathrm{mg} \mathrm{L}^{-1}\right), \mathrm{n}$-heptane $(10 \mathrm{mg}$ $\left.\mathrm{L}^{-1}\right)$, phenol $\left(100 \mathrm{mg} \mathrm{L}^{-1}\right)$, and $\mathrm{NaCl}\left(1000 \mathrm{mg} \mathrm{L}^{-1}\right)$ into distilled water. The synthetic effluent was prepared to generate a concentration of TOC of $145 \mathrm{mg} \mathrm{L}^{-1}$. The selection and concentration of the compounds for the preparation of the synthetic effluent used in this work was established from the values found in literature for oilfield produced waters (Ahmadum et al., 2009; Neff et al., 2011). Furthermore, it was considered that the OPW has already passed by flotation or hydrocyclones, being TOC, the most important parameter to be regulated (Ahmadum et al., 2009). All the reagents used contain analytical grade. 
Adsorption experiments were carried out in a batch system, containing $100 \mathrm{~mL}$ of synthetic solution and $5 \mathrm{~g}$ of adsorbent, under agitation of $120 \mathrm{rpm}$ using a thermostatic orbital shaker, at 25 ${ }^{\circ} \mathrm{C}, 37{ }^{\circ} \mathrm{C}$, and $50{ }^{\circ} \mathrm{C}$, and natural $\mathrm{pH}$ of solution (all the above conditions were based on preliminary tests). At pre-determined times, samples were retrieved, filtered (045 $\mu \mathrm{m}$, Millipore), and forwarded for analysis in a TOC analyzer (V-CPH, Shimadzu). For each time in the kinetic curve, one experiment was carried out. The experiments were performed in triplicate $(n=3)$ and blank tests were performed. The blank tests were carried out also for the filtration step, to avoid any interference of the filter paper in the results. It was found that the filter adsorbed less than $2 \%$, and this value was considered in the calculations. The TOC amount adsorbed at any time $\left(q_{t}, \mathrm{mg}_{\text {Tос }} \mathrm{g}^{-1}\right)$ was evaluated by the TOC reduction $\left(\mathrm{mg} \mathrm{L}^{-1}\right)$ in the solution, as:

$q_{t}=\frac{V_{0} C_{0}-V_{t} C_{t}}{m}$

where, $C_{0}$ is the initial TOC concentration $\left(\mathrm{mg} \mathrm{L}^{-1}\right)$ and $C_{t}\left(\mathrm{mg} \mathrm{L}^{-1}\right)$ is the TOC concentration at time $t$, respectively; $m$ is the amount of adsorbent $(\mathrm{g}) ; V_{0}$ and $V_{t}(\mathrm{~L})$ are the volumes at $t=0$ and along the time, respectively.

\subsection{Adsorption kinetic modeling}

In this work, the adsorption kinetics was used to examine the adsorption rate of TOC from synthetic OPW. For this purpose, pseudo-first order, pseudo-second order, and Elovich equations were used. The kinetic equations of pseudo-first order and pseudo-second order assume that adsorption is a pseudo-chemical reaction, and the adsorption rate can be determined by the equations of pseudo-first (Lagergren, 1898) and pseudo-second order (Ho an Mckay, 1998), respectively, as follows:

$q_{t}=q_{1}\left(1-\exp \left(-k_{1} t\right)\right)$

$q_{t}=\frac{t}{\left(1 / k_{2} q_{2}{ }^{2}\right)+\left(t / q_{2}\right)}$

where, $q_{t}$ is the TOC amount adsorbed at time $\mathrm{t}$ $\left.(\mathrm{mg} \mathrm{g})^{-1}\right), k_{1}$ and $k_{2}$ are the rate constants of pseudo-first and pseudo-second order equations, respectively, in $\left(\mathrm{min}^{-1}\right)$ and $\left(\mathrm{g} \mathrm{mg}^{-1} \mathrm{~min}^{-1}\right), q_{1}$ and $q_{2}$ are the theoretical values for the adsorption capacity $\left(\mathrm{mg} \mathrm{g}^{-1}\right)$ and $t$ is the time ( $\left.\mathrm{min}\right)$.

The Elovich kinetic equation can be described as follows (Zeldowitsch, 1934):

$q_{t}=\frac{1}{b} \ln (1+a b t)$

where, $a$ is the initial velocity due to $d q / d t$ with $\mathrm{q}_{\mathrm{t}}=$ $0\left(\mathrm{mg} \mathrm{g}^{-1} \mathrm{~min}^{-1}\right)$ and $b$ is the desorption constant of the Elovich equation $\left(\mathrm{g} \mathrm{mg}^{-1}\right.$ ).

The parameters were determined by model fits with the experimental kinetic data through nonlinear regression. The parameters were estimated minimizing the least squares function, using the Quasi-Newton estimation method. The calculations were realized using the Statistic 91 software (Statsoft, USA) (El-Khaiary \& Malash, 2011). The fit quality was verified through determination coefficient $\left(R^{2}\right)$ and average relative error (ARE) (Dotto et al., 2013), as follows:

$$
\begin{aligned}
& R^{2}=\left(\frac{\sum_{i}^{n}\left(q_{i, \text { exp }}-\bar{q}_{i, \text { exp }}\right)^{2}-\sum_{i}^{n}\left(q_{i, \text { exp }}-q_{i, \text { model }}\right)^{2}}{\sum_{i}^{n}\left(q_{i, \text { exp }}-\bar{q}_{i, \text { exp }}\right)^{2}}\right) \\
& A R E=\frac{100}{n} \sum_{i=1}^{n}\left|\frac{q_{i, \text { mod } e l}-q_{i, \text { exp }}}{q_{i, \text { exp }}}\right|
\end{aligned}
$$

where, $q_{i, \text { model }}$ is each value of $q$ predicted by the fitted model, $q_{i, \text { exp }}$ is each value of $q$ measured experimentally, $\bar{q}_{i, \text { exp }}$ is the average of $q$ experimentally measured, and $n$ is the number of experimental points.

\section{RESULTS AND DISCUSSIONS}

\subsection{Adsorbents characteristics}

XRD patterns of the adsorbents are shown in Figure 1. The XRD pattern in Figure 1(a) (VAC) shows two bands $\left(2 \theta=2480^{\circ}\right.$ and $\left.4460^{\circ}\right)$ of typically amorphous material (carbon) (Castro et al., 2009; Barroso-Bogeat et al., 2015). Figure 1(b) (BAC) shows diffraction peaks corresponding to the crystal structure of hydroxyapatite $\left[\mathrm{Ca}_{10}\left(\mathrm{PO}_{4}\right)_{6}(\mathrm{OH})_{2}\right]$ (Cazetta et al., 2014; TovarGómez et al., 2013), which is the principal component of bone carbon (Bennett \& Abram, 1967). 

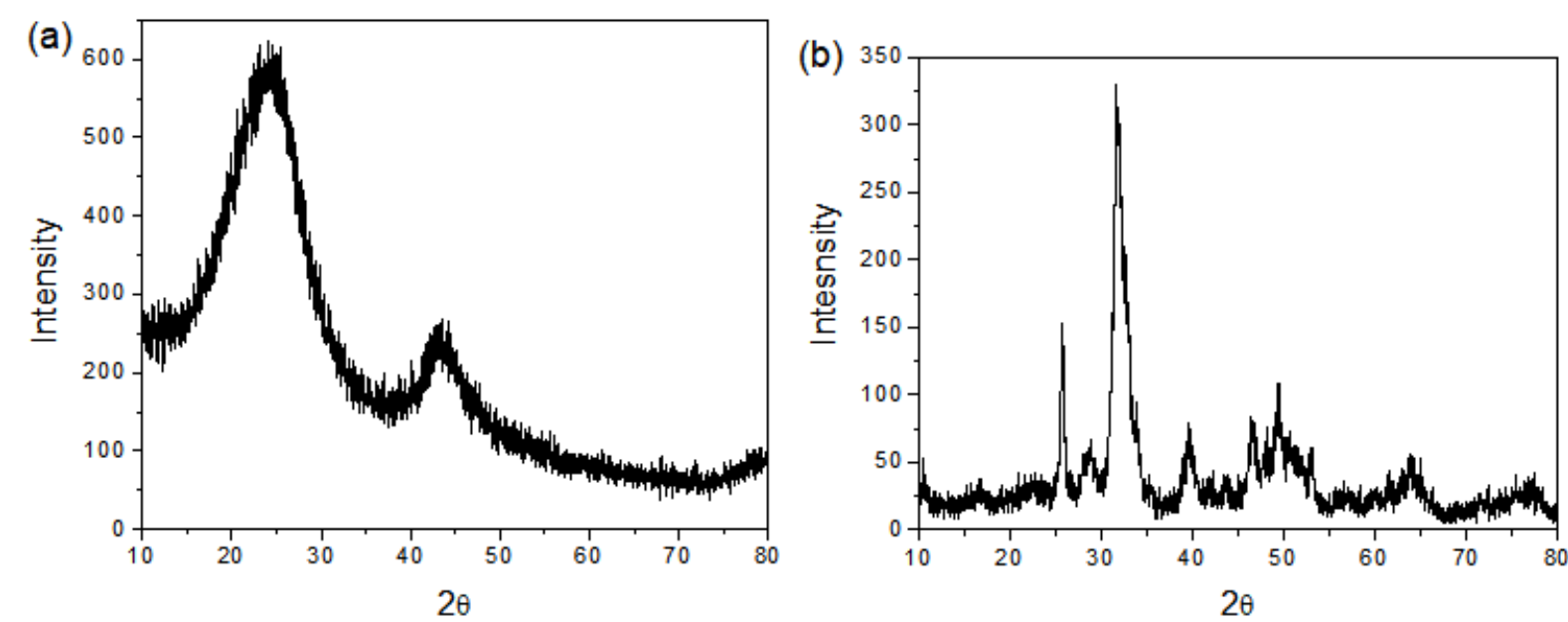

Figure 1. XRD patterns of (a) VAC and (b) BAC adsorbents.
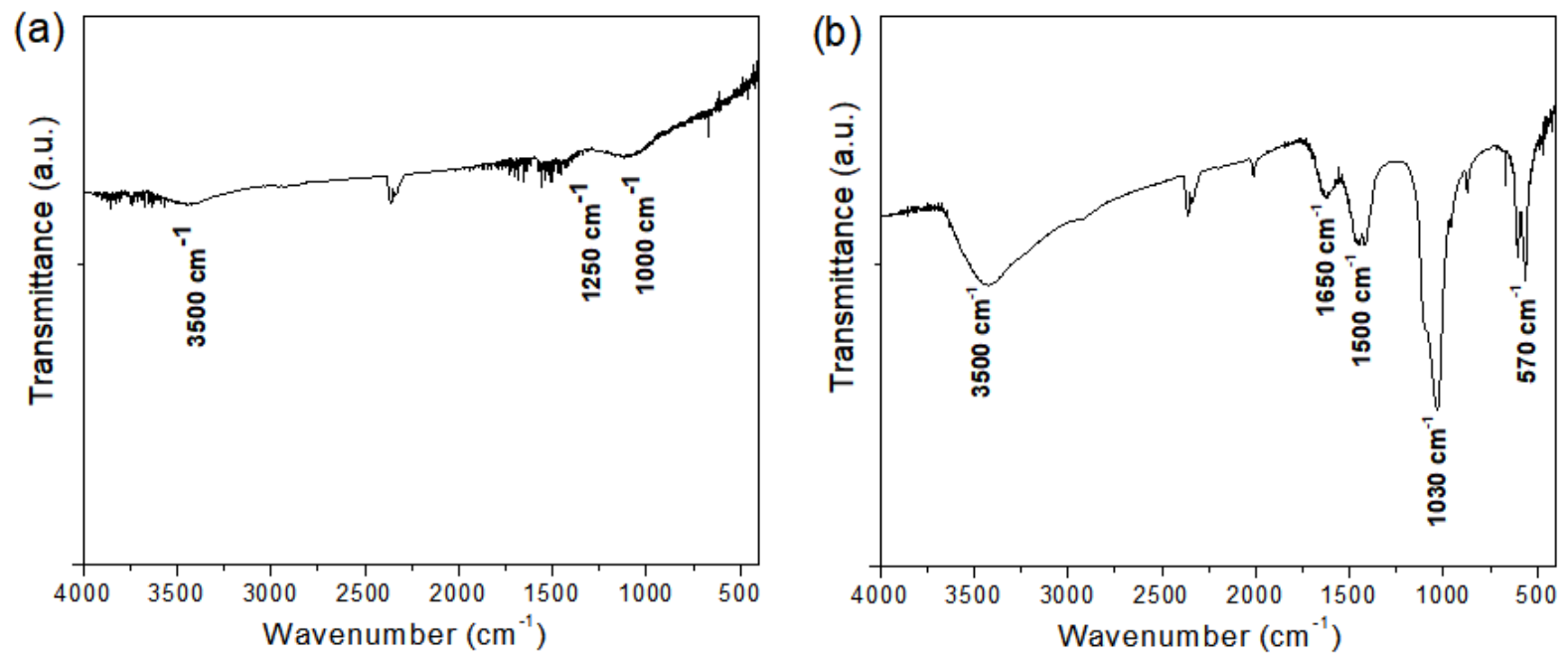

Figure 2. FTIR spectra of (a) VAC and (b) BAC adsorbents.

FTIR spectra of VAC and BAC are shown in Figure 2. FTIR spectrum of VAC (Figure 2a) shows little IR bands at $3500 \mathrm{~cm}^{-1}$ and in the region of $1250-1000 \mathrm{~cm}^{-1}$. The band at $3500 \mathrm{~cm}^{-1}$ is related to the stretch of $\mathrm{OH}$ from phenolic groups, while the region of $1250-1000 \mathrm{~cm}^{-1}$ is relative to the $\mathrm{C}-\mathrm{C}$ and $\mathrm{C}-\mathrm{O}-\mathrm{C}$ links in the carbonaceous skeleton. This behavior is characteristic of amorphous carbonaceous material, indicating that the pyrolysis process performed to obtain the activated carbon from babassu coconut husk led to loss of the majority of chemical groups present in the original material (Foletto et al., 2013). In Figure 2(b), FTIR spectrum of BAC shows the major characteristic bands of the hydroxyapatite structure, located at $1030 \mathrm{~cm}^{-1}$ (assigned to the vibrational stretching of $-\mathrm{PO}_{4}^{-3}$ ) (Cazetta et al., 2014) and at $570 \mathrm{~cm}^{-1}$ (assigned to $\mathrm{Ca}^{2+}$ ) (Lurtwitayapont \& Srisatit, 2010). In addition, the $\mathrm{OH}$ band, typical of activated carbons, also appeared at $3500 \mathrm{~cm}^{-1}$. The bands at 1650 and $1500 \mathrm{~cm}^{-1}$ are due to $\mathrm{C}=\mathrm{O}$ and $\mathrm{C}=\mathrm{C}$ respectively.

The surface structure of the activated carbons was analyzed by scanning electronic microscopy (SEM) (Figure 3). The adsorbent samples VAC (Figure 3a) and BAC (Figure 3b) exhibited a large number of cavities, which favor the diffusion and adsorption of the phenol, xylene, and n-heptane molecules into the internal spaces of the particles. 

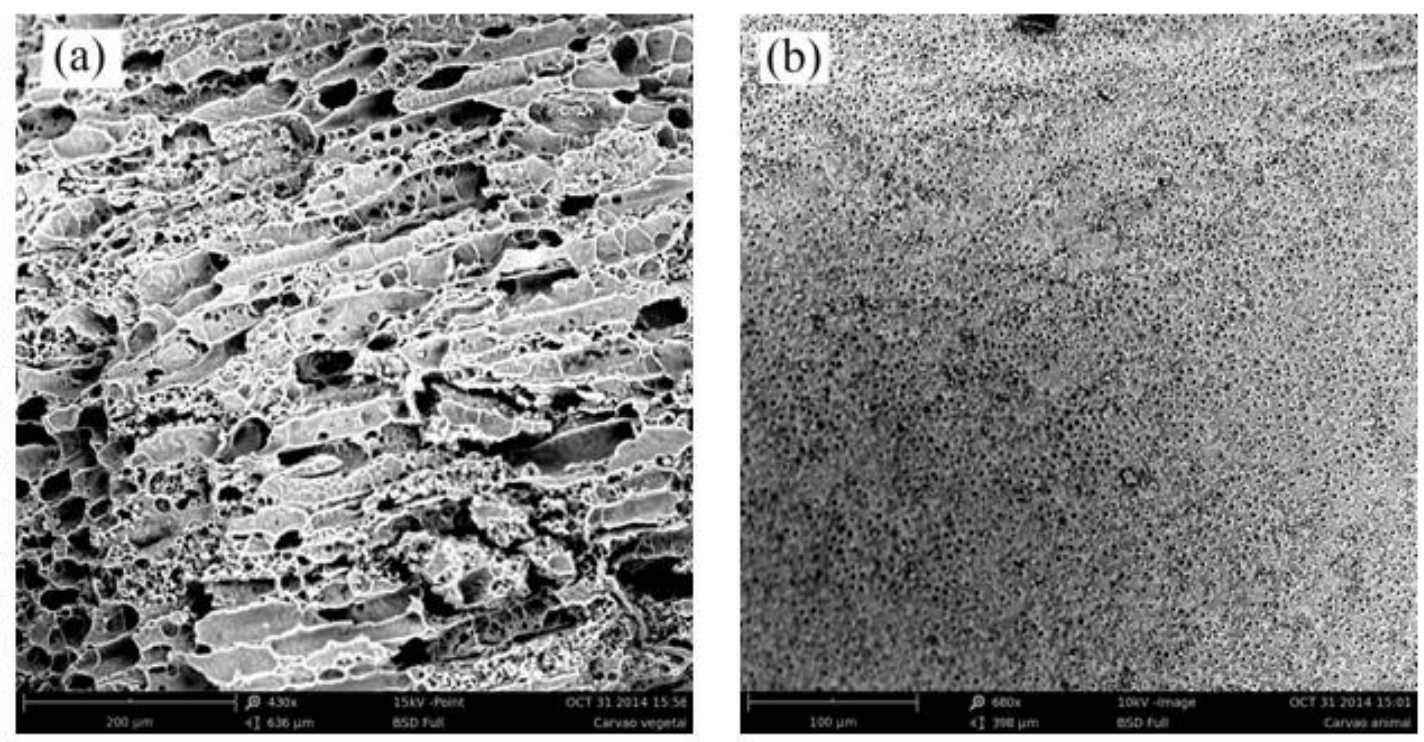

Figure 3. SEM images of (a) VAC and (b) BAC adsorbents. Magnification: 430X (VAC); 680X (BAC).
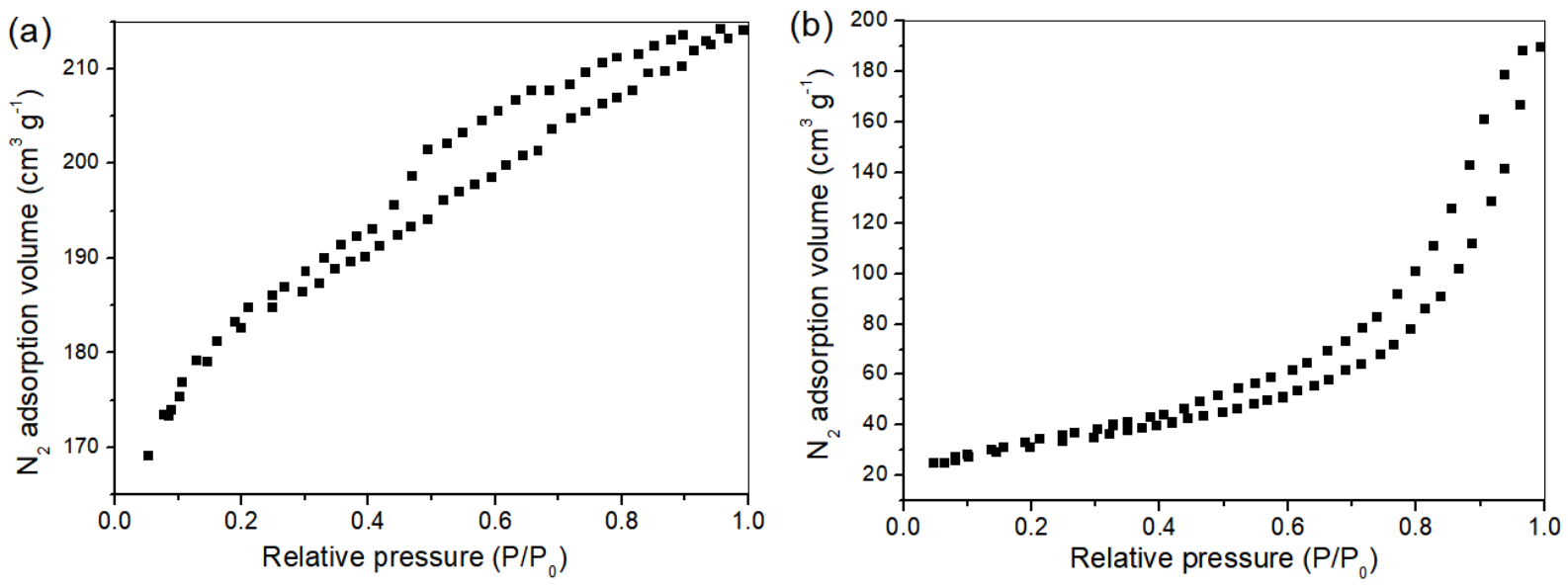

Figure 4. Nitrogen adsorption-desorption isotherms of (a) VAC and (b) BAC adsorbents.

Nitrogen adsorption-desorption isotherms for both samples are displayed in Figure 4 .

The curves can be classified as type IV and, the presence of a hysteresis loop in the nitrogen adsorption-desorption tests indicate that both the adsorbents possess predominantly mesoporous nature. However, the types of hysteresis loop were different for both samples. VAC sample (Figure 4a) presented a type $\mathrm{H} 4$ hysteresis loop, indicating the presence of narrow slit pores. BAC sample (Figure 4b) presented a type $\mathrm{H} 3$ hysteresis loop, indicating plate-like particle aggregates. Therefore, this characteristic is very interesting for adsorption purposes. The values of specific surface area were
109 and $555 \mathrm{~m}^{2} \mathrm{~g}^{-1}$ for the BAC and VAC, respectively. The values of total pore volume and average pore size for the BAC and VAC samples were 0.06 and $0.27 \mathrm{~cm}^{3} \mathrm{~g}^{-1}$, and 3.45 and $3.92 \mathrm{~nm}$, respectively.

\subsection{Temperature effect on the TOC adsorption}

To investigate the temperature effect on the TOC adsorption from OPW onto VAC and BAC adsorbents, kinetic curves were performed at 25, 37 , and $50{ }^{\circ} \mathrm{C}$. The respective results are shown in Figure 5. Below, Figure 5(a) shows that at initial stages, the temperature increase caused a 

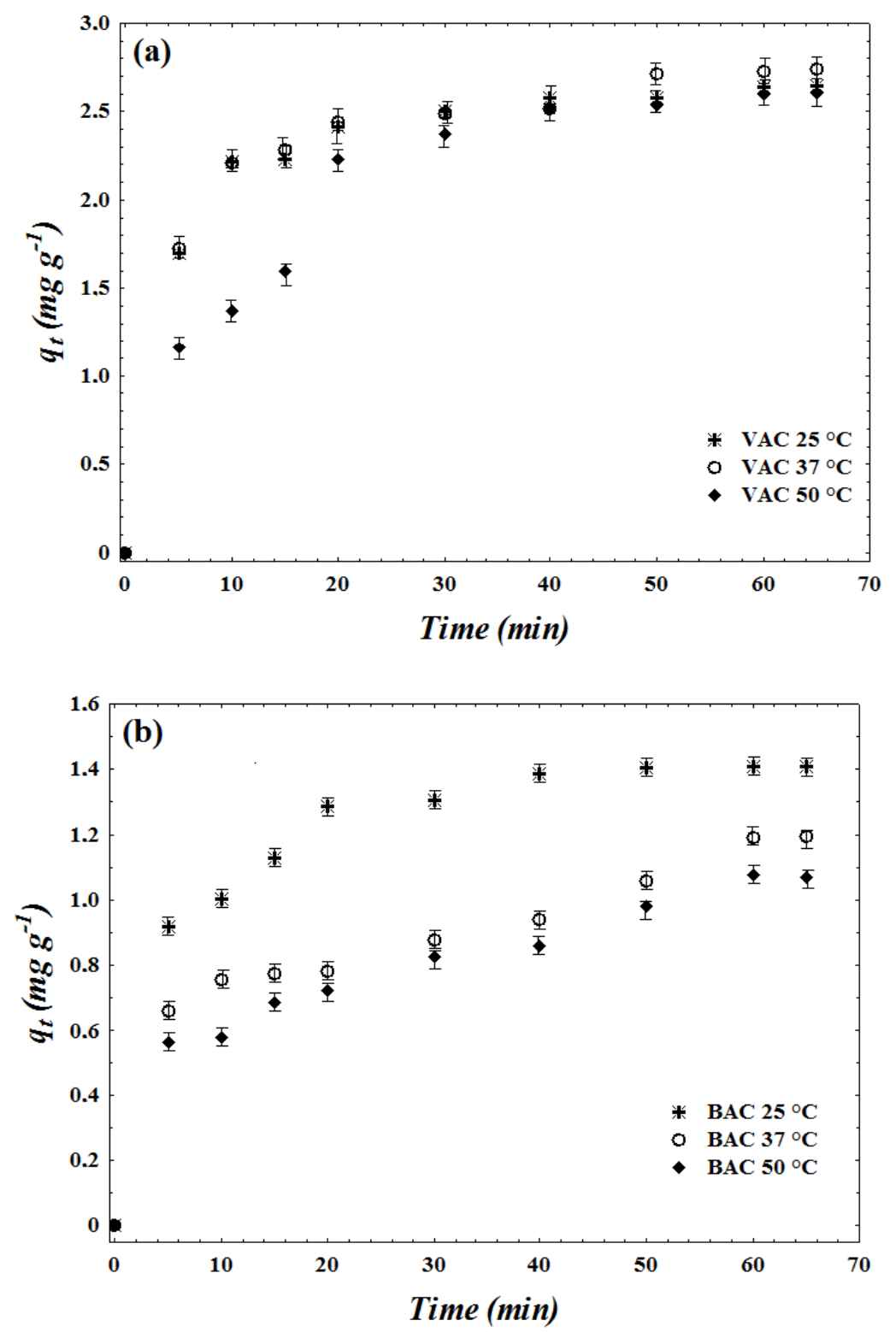

Figure 5. Temperature effect on TOC adsorption using (a) VAC, and (b) BAC adsorbents.

decrease in the adsorbed amount for the VAC adsorbent. However, after $40 \mathrm{~min}$, the adsorbed amount was not temperature dependent, remaining constant around $2.5-2.8 \mathrm{mg} \mathrm{g}^{-1}$ for all temperatures. For BAC adsorbent (Figure $5 b$ ), the temperature increase caused a decrease in adsorbed amount during the entire adsorption period, reaching a maximum capacity of $1.5 \mathrm{mg} \mathrm{g}^{-1}$ for the temperature of $25{ }^{\circ} \mathrm{C}$. The temperature effect can be attributed to the exothermic character of the adsorption process on activated carbons (Ruthven, 1984). Comparing Figures 5(a) and $5(b)$, one can observe that the VAC shows higher adsorbed amount than BAC. The higher adsorbed amount of VAC adsorbent can be ascribed to its highest surface area, which was around five times higher than the BAC surface area. In addition, the VAC sample presented higher pore volume compared to BAC sample.

\subsection{Adsorption kinetic results}

For both adsorbents (VAC and BAC), the adsorption kinetic curves at $25{ }^{\circ} \mathrm{C}$ were modeled using the pseudo-first order, pseudo-second order and Elovich equations. The results are presented in Figure 6 and Table 1. 

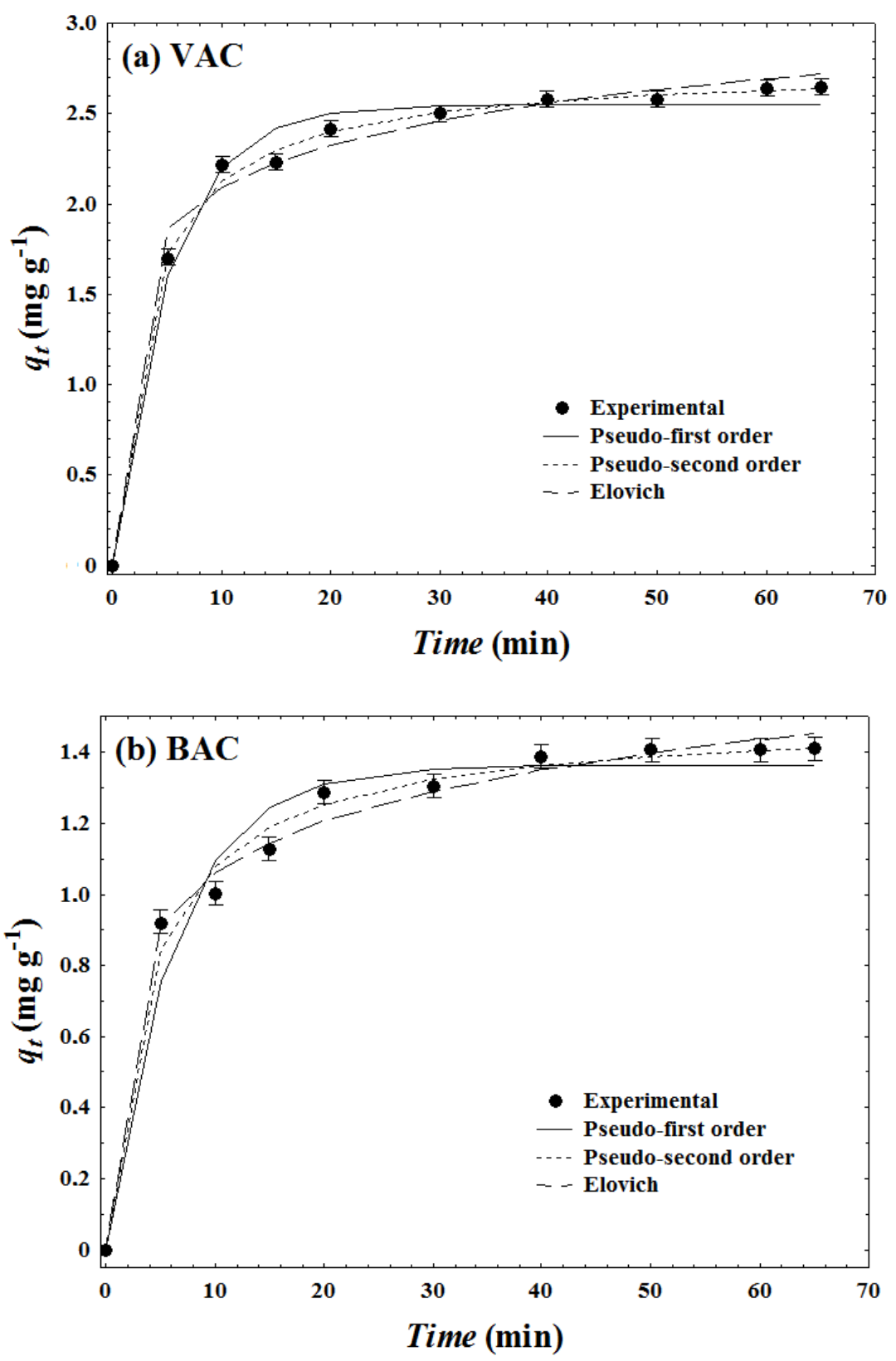

Figure 6. Kinetic curves for the TOC adsorption onto (a) VAC and (b) BAC adsorbents.

Figure 6 reveals that both adsorption processes (using VAC and BAC) presented a similar kinetic profile. Initially, a fast adsorption rate was observed, and around $60 \%$ saturation was attained at $5 \mathrm{~min}$. Then, between 5 and $20 \mathrm{~min}$, a gradual increase in adsorbed amount was observed, reaching around $90 \%$ of saturation. After this time, the adsorption rate decreased, being the adsorption equilibrium attained at around $70 \mathrm{~min}$. The adsorption kinetic parameters are depicted in Table 1. Based on the high values of the coefficient of determination $\left(R^{2}>096\right)$ and on the low values of average relative error (ARE $<60 \%$ ), one can affirm that all the equations were suitable to represent the TOC adsorption from $\mathrm{PW}$, using both VAC and BAC adsorbents. The $q_{1}$ and $q_{2}$ values were similar and agreed with the experimental data. The predicted adsorbed amount for the VAC was two times higher than the BAC. This result confirms that the VAC is more adequate to TOC removal from PW. Moreover, the $k_{1}, a$ and $h_{2}\left(h_{2}=k_{2} q_{2}{ }^{2}\right)$ were higher for the VAC, demonstrating that the TOC adsorption was faster using this adsorbent. 
Table 1. Kinetic parameters for the TOC adsorption from synthetic OPW using VAC and BAC adsorbents.

\begin{tabular}{lcc}
\hline Samples & VAC & BAC \\
\hline Pseudo-first order & & \\
\hline$q_{1}\left(\mathrm{mg} \mathrm{g}^{-1}\right)$ & $2.631 \pm 0.015$ & $1.363 \pm 0.022$ \\
$k_{1}\left(\mathrm{~min}^{-1}\right)$ & $0.1959 \pm 0.0108$ & $0.1622 \pm 0.0017$ \\
$R^{2}$ & 0.9860 & 0.9658 \\
$A R E(\%)$ & 3.14 & 5.39 \\
\hline Pseudo-second order & & \\
\hline$q_{2}\left(\mathrm{mg} \mathrm{g}^{-1}\right)$ & $2.852 \pm 0.011$ & $1.492 \pm 0.031$ \\
$k_{2}\left(\mathrm{~g} \mathrm{mg}^{-1} \mathrm{~min}^{-1}\right)$ & $0.1185 \pm 0.0001$ & $0.1749 \pm 0.0123$ \\
$h_{2}\left(\mathrm{mg} \mathrm{g}^{-1} \mathrm{~min}^{-1}\right)$ & $0.9639 \pm 0.0023$ & $0.3893 \pm 0.0009$ \\
$R^{2}$ & 0.9933 & 0.9894 \\
$A R E(\%)$ & 2.22 & 2.90 \\
\hline Elovich & & \\
\hline$a\left(\mathrm{mg} \mathrm{g}^{-1} \mathrm{~min}^{-1}\right)$ & $15.12 \pm 0.73$ & $3.27 \pm 0.12$ \\
$b\left(\mathrm{~g} \mathrm{mg}^{-1}\right)$ & $2.83 \pm 0.21$ & $4.77 \pm 0.56$ \\
$R^{2}$ & 0.9839 & 0.9913 \\
$A R E(\%)$ & 3.18 & 2.35 \\
\hline
\end{tabular}

The adsorption capacities found in this work were 2.8 and $1.5 \mathrm{mg}_{\text {Tос }} \mathrm{g}^{-1}$ for vegetable and animal activated carbons, respectively. For comparison purposes, Albatrni et al. (2019) used four synthetic resins (Optipore L493, Amberlite IRA958, Amberlite XAD7, and Lewatit AF5) to uptake TOC from produced water. The adsorption capacities ranged from 0.48 to $13.5 \mathrm{mg}_{\text {Tос }} \mathrm{g}^{-1}$ depending of the resin type and experimental conditions. In the work by Azad et al. (2013), various adsorbents were used to remove TOC from wastewater. The adsorption capacities ranged from 0.5 to $20 \mathrm{mg}_{\text {тос }} \mathrm{g}^{-1}$ depending of the adsorbent type and experimental conditions. The most promising materials were activated carbon and $\mathrm{Ni}$ based alumina. Therefore, the results found for $B A C$ and VAC adsorbents are in the range reported in literature for TOC adsorption.

\section{CONCLUSIONS}

Vegetable and animal bone activated carbons were characterized and used as adsorbents to remove TOC from synthetic oilfield produced water. The synthetic oilfield produced water was composed by a mixture of xylene, n-heptane, phenol, and $\mathrm{NaCl}$. Both adsorbents were characterized by X-ray powder diffraction (XRD), scanning electron microscopy (SEM), Fourier transform infrared spectroscopy (FTIR), and $\mathrm{N}_{2}$ adsorption-desorption isotherms. Both materials showed different structural properties because of their different origins. Animal bone and vegetable activated carbons presented surface areas of 109 and $555 \mathrm{~m}^{2} \mathrm{~g}^{-1}$, respectively. For both adsorbents, the TOC adsorption was favored by the temperature decrease, reaching the maximum values at $25{ }^{\circ} \mathrm{C}$. The adsorption kinetic results revealed that the pseudo-first order, pseudosecond order, and Elovich equations were able to represent the adsorption kinetics. The adsorption capacities were 2.8 and $1.5 \mathrm{mg}_{\text {Toc }} \mathrm{g}^{-1}$, for vegetable and animal activated carbons, respectively. In summary, it was found that vegetable activated carbon was more adequate to the TOC removal from synthetic oilfield produced water.

\section{REFERENCES}

Ahmadum, F.R.; Pendashteh, A.; Abdullah, L.C.; Biak, D.R.A.; Madaeni, S.S.; Abidin, Z.Z. Review of technologies for oil and gas produced water treatment. Journal of Hazardous Materials, v. 170 (2-3), p. 530-551, 2009.

https://doi.org/10.1016/i.jhazmat.2009.05.044 
Albatrni, H.; Qiblawey, H.; Almomani, F.; Adham, S.; Khraisheh, M. Polymeric adsorbents for oil removal from water. Chemosphere, v. 233(1), p. 809-817, 2019.

https://doi.org/10.1016/i.chemosphere.2019.05.263

Amini, S.; Mowla, D.; Golkar, M.; Esmaeilzadeh, F. Mathematical modelling of a hydrocyclone for the down-hole oil-water separation (DOWS). Chemical Engineering Research and Design, v. 90(12), p. 2186-2195, 2012.

https://doi.org/10.1016/i.cherd.2012.05.007

Azad, F.S.; Abedi, J.; Iranmanesh, S. Removal of naphthenic acids using adsorption process and the effect of the addition of salt. Journal of Environmental Science and Health, Part A, V. 48(13), p. 1649-1654, 2013.

https://doi.org/10.1080/10934529.2013.815457

Barroso-Bogeat, B.; Alexandre-Franco, M.; Fernández-González, C.; ; Gómez-Serrano, V. Preparation and microstructural characterization of activated carbon-metal oxide hybrid catalysts: New insights into reaction paths. Journal of Materials Science \& Technology, v. 31(8), p. 806814, 2015. https://doi.org/10.1016/i.jmst.2015.06.004

Bennett, M.C.; Abram, J.C. Adsorption from solution on the carbon and hydroxyapatite components of bone char. Journal of Colloid and Interface Science, v. 23(4), p. 513-521, 1967. https://doi.org/10.1016/0021-9797(67)90198-1

Castro, C.S.; Guerreiro, M.C.; Oliveira, L.C.A.; Gonçalves, M.; Anastácio, A.S.; Nazzarro, M. Iron oxide dispersed over activated carbon: Support influence on the oxidation of the model molecule methylene blue. Applied Catalysis A: General, v. 367(1-2), p. 53-58, 2009.

https://doi.org/10.1016/j.apcata.2009.07.032

Cazetta, A.L.; Azevedo, S.P.; Pezoti, O.; Souza, L.S.; Vargas, A.M.M.; Paulino, A.T.; Moraes, J.C.G.; Almeida, V.C. Thermally activated carbon from bovine bone: Optimization of synthesis conditions by response surface methodology. Journal of Analytical and Applied Pyrolysis, v. 110, p. 455462, 2014. https://doi.org/10.1016/i.jaap.2014.10.022

Dórea, H.S.; Bispo, J.R.L.; Aragão, K.A.S.; Cunha, B.B.; Navickiene, S.; Alves, J.P.H.; Romão, L.P.C.; Garcia, C.A.B. Analysis of BTEX, PAHs and metals in the oilfield produced water in the State of Sergipe, Brazil. Microchemical Journal, v. 85(2), p. 234-238, 2007. https://doi.org/10.1016/i.microc.2006.06.002
Dotto, G.L.; Costa, J.A.V.; Pinto, L.A.A. Kinetic studies on the biosorption of phenol by nanoparticles from Spirulina sp. LEB 18. Journal of Environmental Chemical Engineering, v. 1(4), p. 1137-1143, 2013.

https://doi.org/10.1016/i.jece.2013.08.029

Dotto, G.L.; Rodrigues, F.K.; Tanabe, E.H.; Fröhlich, R.; Bertuol, D.A.; Martins, T.R.; Foletto, E.L. Development of chitosan/bentonite hybrid composite to remove hazardous anionic and cationic dyes from colored effluent. Journal of Environmental Chemical Engineering, v. 4(3), p. 3230-3239, 2016.

https://doi.org/10.1016/j.jece.2016.07.004

El-Khaiary, M.I.; Malash, G.F. Common data analysis errors in batch adsorption studies. Hydrometallurgy, v. 105(3-4), p. 314-320, 2011. https://doi.org/10.1016/j.hydromet.2010.11.005

Faksness, L.G.; Grini, P.G.; Daling, P.S. Partitioning of semi-soluble organic compounds between the water phase and oil droplets in produced water. Marine Pollution Bulletin, v. 48(7-8), p. 731-742, 2004.

https://doi.org/10.1016/i.marpolbul.2003.10.018

Foletto, E.L.; Weber, C.T.; Paz, D.S.; Mazutti, M.A.; Meili, L.; Bassaco, M.M.; Collazzo, G.C. Adsorption of leather dye onto activated carbon prepared from bottle gourd: equilibrium, kinetic and mechanism studies. Water Science and Technology, v. 67(1), p. 201-209, 2013. https://doi.org/10.2166/wst.2012.555

Gao, Y.X.; Yang, M.; Zhang, Y.; Hu, J.Y. Treatment of oilfield wastewater by Fenton's process. Water Science and Technology, v. 49(4), p. 103-108, 2004.

https://doi.org/10.2166/wst.2004.0233

Georgin, J.; Dotto, G.L.; Mazutti, M.A.; Foletto, E.L. Preparation of activated carbon from peanut shell by conventional pyrolysis and microwave irradiation-pyrolysis to remove organic dyes from aqueous solutions. Journal of Environmental Chemical Engineering, v. 4(1), p. 266-275, 2016. https://doi.org/10.1016/i.jece.2015.11.018

Ho, Y.S.; Mckay, G. Kinetic models for the sorption of dye from aqueous solution by wood. Process Safety and Environmental Protection, v. 76(2), p. 83-191, 1998.

https://doi.org/10.1205/095758298529326 
Izquierdo, M.T.; Yuso, A.M.; Valenciano, R.; Rubio, B.; Pino, M.R. Influence of activated carbon characteristics on toluene and hexane adsorption: Application of surface response methodology. Applied Surface Science, v. 264, p. 335-343, 2013. https://doi.org/10.1016/i.apsusc.2012.10.023

Jain, P.; Sharma, M.; Kumar, M.; Dureja, P.; Singh, M.P.; Lal, B.; Sarma, P.M. Electrochemical removal of sulfate from petroleum produced water. Water Science and Technology, v. 72(2), p. 284-292, 2015. https://doi.org/10.2166/wst.2015.217

Lagergren, S. About the theory of so-called adsorption of soluble substances, Kungliga Svenska Vetenskapsakademiens, v. 24, p. 1-39, 1898.

Lurtwitayapont, S.; Srisatit, T. Comparison of lead removal by various types of swine bone adsorbents. Environment Asia, v. 3(1), p.32-38, 2010.

Mazlan, M.A.F.; Uemura, Y.; Yusup, S.; Elhassan, F.; Uddin, A.; Hiwada, A.; Demiya, M. Activated carbon from rubber wood sawdust by carbon dioxide activation. Procedia Engineering, v. 148, p. 530-537, 2016.

https://doi.org/10.1016/i.proeng.2016.06.549

Neff, J.; Lee, K.; DeBlois, E.M. Produced Water: Overview of Composition, Fates, and Effects, Chap. 1, p .3-54, In: Lee K., Neff J. (eds), Produced Water, Springer, New York, 2011. https://doi.org/10.1007/978-1-4614-0046-2 1

Oliveira, A.K.C.; Paulo, J.B.A.; Sousa, E.M.B.D.; Lima, K.L.P. Removal of sulfides and oil from produced water. Brazilian Journal of Petroleum and Gas, v. 8(3), p. 81-88, 2014.

https://doi.org/10.5419/bjpg2014-0007

Rashed, M.N. Adsorption Technique for the Removal of Organic Pollutants from Water and Wastewater, Chap. 7, In: Rashed, M.N. (editor), Organic Pollutants - Monitoring, Risk and Treatment, InTech., 2013. Available at: https://www.intechopen.com/books/organicpollutants-monitoring-risk-andtreatment/adsorption-technique-for-theremoval-of-organic-pollutants-from-water-andwastewater

Ruthven, D. Principles of Adsorption and Adsorption Processes, New York, John Wiley \& Sons, 1984.
Santana, C.R.; Pereira, D.F.; Sousa, S.C.S.N.; Cavalcanti, E.B.; Silva, G.F. Evaluation of the process of coagulation/flocculation of produced water using Moringa oleifera Lam as natural coagulant. Brazilian Journal of Petroleum and Gas, v. 4(3), p.111-117, 2010.

https://doi.org/10.5419/bipg2010-0012

Scurtu, C.; Leiknes, T.; Helness, H. Study of an organoclay for the sorption of dissolved organic compounds in the wastewaters from offshore platform operation. Water Science and Technology, v. 59(8), p. 1495-1503, 2009. https://doi.org/10.2166/wst.2009.167

Shpiner, R.; Vathi, S.; Stuckey, D.C. Treatment of oilfield produced water by waste stabilization ponds. Water Science and Technology, v. 55(11), p. 265-271, 2007. https://doi.org/10.2166/wst.2007.366

Silva, S.S.; Chiavone-Filho, O.; Neto, E.L.B.; Foletto, E.L. Oil removal of oilfield-produced water by induced air flotation using nonionic surfactants. Desalination and Water Treatment, v. 56(7), p. 1802-1808, 2015a.

https://doi.org/10.1080/19443994.2014.958103

Silva, S.S.; Chiavone-Filho, O.; Neto, E.L.B.; Foletto, E.L. Oil removal from produced water by conjugation of flotation and photo-Fenton processes. Journal of Environmental Management, v. 147 , p. 257-263, 2015b.

https://doi.org/10.1016/j.jenvman.2014.08.021

Szép, A.; Kohlheb, R. Water treatment technology for produced water. Water Science and Technology, v. 62(10), p. 2372-2380, 2010. https://doi.org/10.2166/wst.2010.524

Tovar-Gómez, R.; Moreno-Virgen, M.R.; DenaAguilar, J.A.; Hernández-Montoya, V.; BonillaPetriciolet, A.; Montes-Morán, M.A. Modeling of fixed-bed adsorption of fluoride on bone char using a hybrid neural network approach. Chemical Engineering Journal, v. 228, p. 1098-1109, 2013. https://doi.org/10.1016/i.cej.2013.05.080

Xu, K.; Liu, Y.; Wang, Y.; Tan, Y.;Liang, X.; Lu, C.; Wang, H.; Liu, X.; Wang, P. A novel poly(acrylic acid-co-acrylamide)/diatomite composite flocculant with outstanding flocculation performance. Water Science and Technology, v. 72(6), p. 889-895, 2015.

https://doi.org/10.2166/wst.2015.290 
Zeldowitsch, J. Über den mechanismus der katalytischen oxydation von $\mathrm{CO}$ an $\mathrm{MnO}_{2}$. Acta Physicochemical, URSS, v. 1(2), p. 449-464, 1934.
Zhang, D.; Huo, P.; Liu, W. Behavior of phenol adsorption on thermal modified activated carbon. Chinese Journal of Chemical Engineering, v. 24(4), p. 446-452, 2016.

https://doi.org/10.1016/i.cjche.2015.11.022 